\title{
Three Cases Resembling Polyarteritis Nodosa Arising During Treatment with Guanethidine
}

\author{
H. A. DEWAR,* M.D., F.R.c.P. ; M. J. T. PEASTON,* M.B., CH.B.
}

Brit. med. F., 1964, 2, 609-611

Widespread inflammation of the walls of small arteries, either in the form of classical polyarteritis nodosa or as a generalized arteritis, has been described as a result of sensitization of the human body to a variety of antigens. Many of these have not been of a protein nature, and then it is assumed that the incriminated substance has acquired its antigenic properties by becoming linked to a protein in the plasma. Drugs suspected of being incriminated in this way have included antibiotics such as chloramphenicol (Rose and Spencer, 1957), penicillin (Waugh, 1952; Winton and Nora, 1955), streptomycin (Edge et al., 1955); sulphonamides (Rose and Spencer, 1957 ; Lichtenstein and Fox, 1946); organic arsenic compounds (Miller and Daley, 1946); barbiturates (Meyler et al., 1960) ; chlorpromazine (Symmers, 1958) ; corticosteroids (Slocumb et al., 1957 ; Rose and Spencer, 1957); D.D.T. (Hill and Damiani, 1946); hydantoin derivatives (Van Wyk and Hoffman, 1948); hydrallazine (Symmers, 1962); iodides (Rasmussen, 1955) ; metals such as bismuth (Rose and Spencer, 1957), gold (Meyler et al., 1960), and mercury (Winton and Nora, 1955); phenylbutazone (Hodge and Lawrence, 1957) ; quinidine (Symmers, 1962) ; and uracil compounds (McCormick, 1950; Dalgleish, 1952). There are doubtless others, but we have not been able to find any reference to guanethidine as the antigen in an allergic vasculitis. In the following three cases it seems possible that it has been the responsible factor.

\section{Case 1}

This patient, a woman aged 68 , had no family history of hypertension but was found in 1955 to have a blood-pressure of $200+/$ $140 \mathrm{~mm}$. $\mathrm{Hg}$, which despite mecamylamine and bretylium tosylate worsened, until in 1960 it reached 260/150 and urea clearance was only $32 \%$ of normal average. She had some blackouts, which were probably epilepsy and were fully controlled by phenobarbitone. She was then given guanethidine, 30-60 mg. daily, in combination with mecamylamine and chlorothiazide, but with indifferent success. Her weight, however, at this time was steady. From July 1961 she took guanethidine only, $15 \mathrm{mg}$. daily, with phenobarbitone and an occasional dose of atropine to control diarrhoea. In August she increased the guanethidine to $20 \mathrm{mg}$. daily and almost at once developed paraesthesiae in her left leg.

By October there was severe right foot-drop with considerable sensory loss of the outer leg below the knee, and also moderate numbness on the dorsum of the left foot and part of the right hand. Knee-jerks were brisk, but the left ankle-jerk was weak and the right one absent. The left plantar response was flexor and the right was absent. There was now fever, $99-100^{\circ} \mathrm{F}$. $\left(37.2-37.8^{\circ} \mathrm{C}\right.$.), an E.S.R. of $52 \mathrm{~mm}$. in 1 hour (Westergren), and she had lost weight. Blood-pressure was 205/130. Wassermann reaction was negative. Urine contained a trace of albumin but no blood. C.S.F. was normal. Hb was 11 g./100 ml., M.C.V. 98 cubic microns, M.C.H.C. $32.4 \%$, W.B.C. 15,000 (polymorphs $85 \%$, lymphocytes $12 \%$, eosinophils $2 \%$, monocytes $1 \%$ ). Bone-marrow was normoblastic. Blood urea was $50 \mathrm{mg} . / 100 \mathrm{ml}$., sugar tolerance was normal, L.E. cells were not found. Muscle biopsy was normal. Tests for virus infection were negative. With steroid therapy (prednisone $20 \mathrm{mg}$. daily) the E.S.R. and body temperature returned

\footnotetext{
- From the Royal Victoria Infirmary, Newcastle upon Tyne, and Queen
} Elizabeth Hospital, Gateshead. to normal, but the neuritis did not improve, and in December it was noted that the right foot was cold and red and pulses could not be felt below the popliteal. A possible connexion between guanethidine and the presumed polyarteritis was suspected, but because of the severe hypertension and its lack of response to other therapy this was not acted upon and the drug was continued in dosage of $20 \mathrm{mg}$. daily in addition to the steroid therapy.

By May 1962 the patient's general condition was fair but she could not walk, and she noticed that her hair was beginning to fall out. This worsened over the next few months. In November 1962 she developed symptoms and signs of acute appendicitis, and at operation this was confirmed and general peritonitis found. A biopsy specimen from the internal oblique muscle of the abdomen was histologically normal, but the appendix showed a " necrotizing arteritis, some of the lesions being acute and others distinctly older; they did not suggest a reaction to hypertension" (Professor A. G. Heppleston). After operation she developed a faecal fistula, passed into heart failure and uraemia, and died on 13 December 1962. Necropsy was not obtained.

\section{Case 2}

A schoolmaster aged 67 was first seen in 1958 because of an attack of pain in the upper chest and left shoulder and was found to have a blood-pressure of $240 / 130 \mathrm{~mm}$. $\mathrm{Hg}$. There was a history of septicaemia three years before but the kidneys had not been involved. He was admitted to hospital for investigation and treatment. Urine was normal and urea clearance $96 \%$ of normal average. E.C.G. showed early left ventricular hypertrophy. Treatment with mecamylamine and chlorothiazide brought standing blood-pressure to about $160 / 100$, but control was irregular and constipation very troublesome. In May 1960 he was therefore changed to guanethidine, of which $60 \mathrm{mg}$. a day with chlorothiazide $0.5 \mathrm{mg}$. six days a week kept his blood-pressure at 175/90 sitting and 145/95 standing, and it remained at this level until November 1961. The patient was well and working regularly.

At this date, without any preliminary sore throat, he developed a rash on his legs. This cleared in a few days, but he then became ill with what seemed to be a mild fever and rather severe pains which increased in severity. They were chiefly in the hands, forearms, and elbows, and for a time in the right ankle. Salicylates caused abdominal pain and vomiting and gave little relief to his symptoms. Fever ranged between 98.6 and $99.4^{\circ} \mathrm{F}$. (37 and $37.4^{\circ}$ C.). The joints were not swollen, muscle power was quite good, and all reflexes were present and equal, but there was some tender swelling of the forearm muscles. The radial artery was also rather tender and on the left side a small aneurysm appeared near the wrist, and the muscles of this forearm were also tender. In the heart there was a soft systolic murmur at the apex; blood-pressure was 140/80. Urine contained albumin and some red cells. Blood urea was $72 \mathrm{mg} . / 100 \mathrm{ml}$. and plasma proteins were $5.3 \mathrm{~g} . / 100 \mathrm{ml}$. (albumin $2.8 \mathrm{~g}$., globulin $2.5 \mathrm{~g}$.) with some increase in the gammaglobulin fraction. Serum transaminase was normal, E.S.R. $60 \mathrm{~mm}$. in 1 hour (Westergren), Hb $10.8 \mathrm{~g} / 100 \mathrm{ml}$., W.B.C. 10,500 (polymorphs $84 \%$, only $2 \%$ eosinophils). L.E. cells were not seen. Muscle biopsy showed definite but scanty evidence of polyarteritis.

Guanethidine was continued and prednisone $50 \mathrm{mg}$. a day begun. The patient improved rapidly, the albuminuria gradually disappearing, but his anaemia persisted for rather a long time and required repeated blood transfusions. A month later urea clearance was $63 \%$ of the normal and resting blood urea was normal. The prednisone was gradually reduced over succeeding months and by May 1962 he was fit to start work again, his E.S.R. having fallen to $7 \mathrm{~mm}$. in 1 
hour. Hypertension, however, persisted, with blood-pressure 210/ 120 sitting and $160 / 100$ standing, on a dosage of $60 \mathrm{mg}$. of guanethidine a day. By September 1962 prednisone had been reduced to $10 \mathrm{mg}$. a day and the E.S.R. remained satisfactory at $7 \mathrm{~mm}$. in 1 hour. Further reduction of prednisone, however, caused some rise in the E.S.R., so it has been continued. Blood-pressure remains satisfactory at $140 / 100$ and the patient is very well.

\section{Case 3}

A woman aged 56 was first noted to be hypertensive in 1952, when a systolic reading of $280 \mathrm{~mm}$. $\mathrm{Hg}$ was recorded. She was admitted to hospital in 1959 for investigation and treatment. She had no fever and the initial blood-pressure reading was 280/130. She was treated for 20 months with mecamylamine, $15-30 \mathrm{mg}$. daily. Because of an episode of vomiting she was readmitted in April 1960 ; there was still no fever, and on this admission treatment was changed to guanethidine in a dosage of $15 \mathrm{mg}$. a day. She remained well and her weight steady during the next nine months, and then in January 1962 she abruptly developed vomiting, giddiness, nystagmus, ataxia, and diplopia. This episode was assumed to be due to a brain-stem thrombosis and after it she became hypersensitive to guanethidine, which was therefore temporarily discontinued. Blood-pressure, however, rose to $260 / 125$ and the drug was resumed in a reduced dosage of $5 \mathrm{mg}$. daily. Ataxia however, worsened, and in May she was bed-ridden with general weakness, marked dulling of intellect, disorientation of time and space, and a very poor memory. There was sustained nystagmus when she looked to the right and cerebellar ataxia of all limbs. Muscular power was diminished but reflexes were initially all brisk and equal. Later, however, a right spastic hemiparesis appeared with extensor plantar response.

The patient was admitted to hospital at the end of May and was found to have a low-grade intermittent pyrexia of $99-100^{\circ} \mathrm{F}$. (37.2$37.8^{\circ}$ C.), E.S.R. $132 \mathrm{~mm}$. in 1 hour (Westergren), and a normochromic anaemia $\mathrm{Hb} 10.5 \mathrm{~g} . / 100 \mathrm{ml}$. Other investigations included total white-cell count 7,000 (polymorphs $78 \%$, lymphocytes $16 \%$, monocytes $2 \%$, eosinophils $4 \%$ ), and reticulocytes less than $1 \%$. L.E. cells were not found. Marrow films were normal. Urine contained a trace of albumin but no Bence Jones proteose and no blood. Blood urea was $40 \mathrm{mg} . / 100 \mathrm{ml}$. Several blood cultures were sterile. Liver-function tests including S.G.O.T. were normal and plasma proteins $6.3 \mathrm{~g} . / 100 \mathrm{ml}$. Wassermann reaction was negative. $X$-ray examination of the chest showed some cardiac enlargement only. C.S.F. on 6 June showed less than 1 cell/c.mm., protein $55 \mathrm{mg} . / 100 \mathrm{ml}$., and globulin negative, and on 4 September 2 lymphocytes per c.mm., protein $100 \mathrm{mg} . / 100 \mathrm{ml}$., and globulin negative. Electroencephalogram under sedation showed slight excess of theta activity only and no focal lesion. Muscle biopsy showed a little secondary muscle atrophy (shrinkage, sarcolemmal nuclear crowding, and some centralization), consistent with peripheral neuropathy, but no evidence of myositis or arteritis. Blood-pressure while she was in hospital did not exceed $175 / 90$, so no further guanethidine was given.

Her general condition slowly deteriorated, and after some weeks of observation, during which no infective or neoplastic cause for the fever was found, treatment with steroid, prednisone $40 \mathrm{mg}$. a day, was begun. Improvement was immediate and fever disappeared, E.S.R. fell rapidly to $13 \mathrm{~mm}$. in 1 hour, she became much stronger and gradually got on to her feet again. Her mental state also steadily improved. At the end of four months' treatment she could speak and write clearly and sensibly, though her mood was rather euphoric and articulation slightly slurred. She could walk in the street on her own but was rather unsteady. Tendon reflexes remained very brisk and rather more so on the right, but both plantar responses became flexor. Haemoglobin rose to $15.5 \mathrm{~g} . / 100 \mathrm{ml}$. With reduction of prednisone dosage to $10 \mathrm{mg}$. daily, E.S.R. rose to $60 \mathrm{~mm}$. in 1 hour, but she appeared to be holding her own.

When last seen in July 1963 the E.S.R. was $27 \mathrm{~mm}$. in 1 hour, while she was on a dosage of $10 \mathrm{mg}$. of prednisone daily. Her blood-pressure remained at about 215/105 without hypotensive drugs of any kind.

Dr. J. N. Walton, consultant neurologist, saw her when she was beginning to recover and reported: "I can only agree with you entirely that the manifestations are those of cerebral vascular disease with diffuse involvement of the cerebral tree. The patient is now demented, vague, and inconsequential, but there is no aphasia, and it seems that she is slowly recovering from her recent episode of left hemisphere infarction, although there is a marked residual dysarthria with some euphoria, suggesting that almost certainly there has been some bilateral softening. It certainly looks very much from the result of your investigation as though this woman's diffuse arterial disease has been the result of a hypersensitivity phenomenon and that, despite the lack of histological confirmation, the primary pathological cause must be either polyarteritis nodosa or possibly disseminated lupus, though the former seems much the more probable. Certainly there is no suggestion of a cranial giant-cell arteritis or of cerebral Buerger's disease, which may sometimes give a similar picture, and I think that polyarteritis is much the most probable explanation, though I do not see how this can be proved."

\section{Discussion}

Although histological proof of the diagnosis of polyarteritis was obtained in only two of the above patients, there does not seem to be much doubt about the other. The arguments for its inclusion have been well marshalled by Dr. Walton.

Case 1, presenting with mononeuritis multiplex, also demonstrated one unusual feature in that during the course of the disease much of the patient's hair continued to fall out. This has been described once as a feature of guanethidine toxicity (A. K. Pittman, personal communication 1962) but might equally be attributable to the arteritis. This patient responded very poorly to steroid therapy, for her hypertension was of long standing and severe, and she died of a visceral complication of the arteritis which had been confirmed by biopsy of the appendix. The guanethidine treatment was continued after the onset, partly because the hypertension was really severe and would not respond to anything else, and partly because at that time a possible causal relationship between drug and disease was not appreciated.

Case 2, presenting as classical polyarteritis nodosa, has responded very well to treatment and remains in remission two years after onset, though the patient still needs a maintenance dose of steroid and hypotensive therapy. His progress on both has been so good that it seemed unwise to disturb it.

Case 3, presenting as cerebral vasculitis, is in incomplete remission and still needs a maintenance dose of prednisone. The hypertension, however, has disappeared and no longer needs treatment, possibly because the cerebral features included partial infarction of the brain-stem.

The duration of hypertension prior to onset of symptoms, together with the dosage of guanethidine and the duration of its administration, is set out in the Table. This also lists the drugs given concurrently with guanethidine.

The important question in the series is obviously the possible relation between the patients and their drug treatment. It might be argued that the original hypertension for which treatment was instituted was itself a manifestation of pre-existing but latent polyarteritis. The length of time that this severe hypertension had been present $(6,4$, and 10 years respectively) seems to refute this proposition. A second possibility is that the polyarteritis developed spontaneously in the course of each patient's hypertension and that guanethidine and chlorothiazide happened to be the drugs in use at that time-the "secondary periarteritis" of Knowles et al. (1953). If so it is a striking coincidence, for one of us has been treat-

Duration of Hypertension, and Dosage and Duration of Guanethidine

\begin{tabular}{c|c|c|c|c}
\hline $\begin{array}{c}\text { Case } \\
\text { No. }\end{array}$ & $\begin{array}{c}\text { Duration of } \\
\text { Pre-existing } \\
\text { Hypertension } \\
\text { (Years) }\end{array}$ & $\begin{array}{c}\text { Dosage of } \\
\text { Guanethidine } \\
\text { (Mg./day) }\end{array}$ & $\begin{array}{c}\text { Duration of } \\
\text { Guanethidine } \\
\text { Therapy } \\
\text { (Years) }\end{array}$ & $\begin{array}{c}\text { Other Drugs } \\
\text { Given } \\
\text { Concurrently }\end{array}$ \\
\hline 1 & 6 & $15-60$ & $1 \frac{1}{2}$ & $\begin{array}{l}\text { Phenobarbitone. Atro- } \\
\text { pine occasionally. } \\
\text { ??Chlorothiazide } \\
\text { Chlorothiazide } \\
\text { None }\end{array}$ \\
\hline
\end{tabular}


ing large numbers of hypertensive patients for long periods during the past ten years with a variety of drugs and does not recollect having any other cases of polyarteritis supervene during their management. Moreover, since these three cases have been made known two other possible cases of collagen disease attributable to guanethidine have been brought to our notice. In one case, belonging to Dr. A. R. Horler (personal communication, 1963), fever, polyarthritis, and polyneuritis followed treatment of hypertension with guanethidine, pempidine, and chlorothiazide. In the other, reported to us by Professor J. T. Ingram (personal communication, 1963), disseminated lupus erythematosus developed in a patient taking guanethidine and digoxin. It is not claimed, however, that the case for a causal relationship has been established with certainty. But in view of its potential importance it has been thought wise to present the facts. The possibility of chlorothiazide as a causal agent has also been considered, since it too was being taken with guanethidine in one of the cases and possibly in two of them; but it is so widely used for other purposes without harm accruing that this seems unlikely. As to the possible significance of the combination of guanethidine and chlorothiazide, no evidence is offered. It could apply to only two of the cases here presented.

\section{Summary}

Three cases are described in which " collagen vascular disease" developed during treatment of long-standing hypertension with guanethidine.
They presented as mononeuritis multiplex, polyarteritis nodosa, and cerebral vasculitis respectively.

A possible causal relationship with guanethidine is discussed.

Our thanks are due to Professor A. G. Heppleston for the biopsy report on Case 1 ; to Dr. A. R. Horler and Professor J. T. Ingram for permission to quote their two other cases of possible sensitivity ; and to Dr. J. N. Walton for his neurological opinion upon Case 3.

\section{REFERENCES}

Dalgleish, P. G. (1952). Lancet, 2, 319.

Edge, J. R., Fazlullah, S., and Ward, J. (1955). Ibid., 1, 1153.

Hill, W. R., and Damiani, C. R. (1946). New Engl. f. Med., 235, 897.

Hodge, P. R., and Lawrence, J. R. (1957). Med. F. Aust., 1, 640.

Knowles, H. C., Zeek, P. M., and Blankenhorn, M. A. (1953). Arch. intern. Med., 92, 789.

Lichtenstein, L., and Fox, L. J. (1946). Amer. F. Path., 22, 665.

McCormick, R. V. (1950). f. Amer. med. Ass., 144, 1453.

Meyler, L., Stoel, L., Hogewind, F., Kooy, A. N. F., and Loonstra, Ti. (1960). Acta med. scand., 167, 95.

Miller, H. G., and Daley, R. (1946). Quart. F. Med., 15, 255.

Rasmussen, H. (1955). F. Allergy, 26, 394.

Rose, G. A., and Spencer, H. (1957). Quart. 7. Med., 26, 43.

Slocumb, C. H., Polley, H. F., and Ward, L. E. (1957). Proc. Mayo Clin., 32, 227.

Symmers, W. St. C. (1958). Symposium C.I.O.M.S. Scientific Publ. Oxford, p. 209.

- (1962). Proc. roy. Soc. Med., 55, 20.

Van Wyk, J. J., and Hoffman, C. R. (1948). Arch. intern. Med., 81, 605.

Waugh, D. (1952). Amer. F. Path., 28, 437.

Winton, S. S., and Nora, E. D. (1955). Amer. F. Med., 18, 66.

\title{
Recovery from Presumed Subacute Inclusion-body Encephalitis
}

\author{
J. M. S. PEARCE, ${ }^{+} \dagger$ M.B., M.R.C.P. ; D. D. BARWICK, ${ }^{*}$ M.B., M.R.C.P.ED.
}

Brit. med. 7., 1964, 2, 611-613

Subacute inclusion-body encephalitis was first reported by Dawson (1934) as a disease of children characterized by the finding of type $A$ inclusions in the nuclei of cortical neurones. Similar cases were subsequently described (van Bogaert, 1945 ; van Bogaert et al., 1956) under the title of "subacute sclerosing leucoencephalitis," and it is now believed that these two syndromes are identical (Greenfield, 1950). The disease affects children and young adults and has an insidious afebrile onset, usually with deterioration of personality and behaviour and sometimes associated with epilepsy. The second stage is characterized by akinetic mutism with complex involuntary movements, myoclonic or ballistic, occurring at intervals of 5-10 seconds and accompanied by synchronous periodic highvoltage complexes followed by periods of electrical silence in the electroencephalogram (E.E.G.). The third and final stage is one of progressive decortication leading to death within months or at the most two years. Excellent reviews of the clinicopathological findings are given by Dawson (1934), van Bogaert et al. (1956), Foley and Williams (1953), Pallis and

\footnotetext{
- Department of Neurology, Regional Neurological Centre, General Hospital, Newcastle upon Tyne.

† Present address: Senior Registrar, Department of Neurology, the General Infirmary at Leeds.
}

Spillane (1957), Poser and Radermecker (1959), and by Brain et al. (1948).

Remissions are occasionally seen in the early stages (Simpson, 1961), but recovery is so rare that in Simpson's Case 11, when apparent recovery occurred, he concluded that the diagnosis was incorrect. One non-fatal case was recorded by Kurtzke (1956), who accepted the diagnosis.

We report below a patient who was believed to be suffering from this condition but who has apparently made a complete recovery.

\section{Case Report}

A 17-year-old boy was sent home from school on 14 June 1963 complaining of tiredness, loss of appetite, and a sore throat. He developed a generalized headache and drowsiness, and in the next few days exhibited severe behaviour disturbances, notably swearing, saying and doing inappropriate things, and being restless and totally disorientated. These symptoms led to his admission to a psychiatric unit, where physical examination disclosed no neurological signs, but an E.E.G. showed a doubtful focus in the right posterior temporal region. On 22 June, after an injection of methedrine, he had a major epileptic seizure followed by status epilepticus, which was controlled with paraldehyde and barbiturates. 